\section{Self- and Cross-compatibility among Apricot Cultivars}

\author{
L. Burgos ${ }^{1}$, T. Berenguer, and J. Egea \\ Department of Fruit Breeding, Centro de Edafologia y Biologia Aplicada de1 \\ Segura-Consejo Superiorde Investigaciones Cientificas, Apartado de Correos \\ 4195,30080 Murcia, Spain
}

Additional index words. fruit set, pollen tube growth, Prunus armeniaca

Abstract. Eight apricot (Prunus armeniaca L.) cultivars were self- and cross-pollinated to determine pollen compatibility. Pollen tube growth in the laboratory and the percentage of fruit set in the orchard were evaluated. The results confirmed that 'Moniqui Fino' and 'Velázquez Tardío' are self-incompatible and established that 'Gitano', 'Pepito del Cura', and 'Velázquez Fino' are also self-incompatible. No cross-incompatibility was found in the 25 cross-combinations.

The economic importance of fruit-tree cultivar self- and cross-pollination has grown. Monovarietal plantations of self-incompatible species have resulted in considerable financial losses. Studies of several species have emphasized the improved yield that can be obtained by cross-pollination (Free and SpencerBooth, 1964; Godini et al., 1979; Socias i Company et al., 1976).

European apricot cultivars traditionally have been considered self-compatible (Bailey and Hough, 1975), a hypothesis that has been confirmed by testing many cultivars. No case of self-incompatibility was reported in Cappellini and Limongelli (1981) or Limongelli and Cappellini (1978). Self-incompatible cultivars have been described by other researchers, however. Nyútjó et al. (1985) found one self-incompatible accession among 23 cultivars tested, and Lamb and Stiles (1983) described five such cases. Schultz (1948) found the American cultivars Perfection and Riland to be self-incompatible.

In the region of Murcia, Spain, the foremost apricot-producing region of Europe, unexplained crop failures are frequent among local cultivars. Egea et al. (1991) revealed selfincompatibility in two cultivars, and Garcia et al. (1988) found pollen sterility in two others. Both phenomena probably caused low fruit productivity. The objective of our research was to examine self- and cross-compatibility in a group of Murcia apricot cultivars.

Three techniques were used to determine whether self- or cross-incompatibility existed among cultivars with overlapping flowering periods:

- Natural self-pollination. For each cultivar, three branches with most flower buds in

Received for publication 8 May 1992. Accepted for publication 24 Aug. 1992. The cost of publishing this paper was defrayed in part by the payment of page charges. Under postal regulations, this paper therefore must hereby be marked advertisement solely to indicate this fact.

'Current address: Dept. of Genetic and Postharvest Quality, U.S. Dept. of Agriculture-Agricultural Research Service, Peach Ave., Fresno, CA 93727. the balloon stage were selected. Open flowers and late buds were removed, and branches were bagged using water-proof sulfurized or paraffin paper to avoid crosspollination. The bags were taken off after 8 weeks and fruit set was determined.

- Field-controlled pollination. Controlled pollinations among the cultivars being studied were carried out, using the tree's own pollen and pollen of other cultivars that bloom at about the same time. Before pollination, pollen was collected from all cultivars by desiccating the anthers in a petri dish at ambient temperature. In the field, branches were chosen that had an average of 60 to 70 flowers in the balloon stage. The flowers were emasculated to prevent self-pollination. After 8 weeks, the fruit were counted and the fruit set percentage was determined.

- Laboratory-controlled pollination. During the first year, all crosses carried out in the field were repeated in the laboratory to compare the results. Since the laboratory method was shown to be reliable, crossfertilization was carried out in the laboratory only during the following year.

Branches with $\approx 20$ flowers in balloon stage of the cultivars to be pollinated were cut and placed in a plastic bag containing water. The bags were transported to the laboratory in an insulated ice chest. In a chamber where the temperature was maintained at $20 \mathrm{C}$, the branch ends were put in beakers with a $5 \%$ sucrose solution. The flowers were emasculated immediately and left for $24 \mathrm{~h}$ before being pollinated. The pollen was prepared as mentioned above.

At 12,48 , and $72 \mathrm{~h}$ after controlled pollination, 15 emasculated flowers were picked and placed in small glass bottles containing a $5 \%$ formaldehyde fixing solution at $40 \%, 5 \%$ acetic acid, and $90 \%$ ethanol at $70 \%$ (FAA). This solution is commonly used for fixing pistils stored at 4 to $5 \mathrm{C}$ before being examined.

The pistils were washed and placed in an autoclave for $30 \mathrm{~min}$ at $1 \mathrm{~atm}$ in a $5 \%$ sodium sulfite solution to soften the flowers and facilitate their staining with $0.1 \%$ aniline blue in 0.1
$\mathbf{N}$ potassium phosphate. The pistils were stained for $24 \mathrm{~h}$, after which the epidermis was removed and the pistils squashed for observation (Linskens and Esser, 1957). An Olympus BH2 microscope (Olympus, Tokyo) was used with a BH2-RFL-T2 ultraviolet light source, using an Osram HBO 100 W/2 high-pressure mercury lamp (Osram GmbH, Berlin-Munich).

Pollen germination in the stigma was classified as low ( $<15$ grains), medium (15 to 40 grains), and high ( $>40$ grains). The length of the longest pollen tube was measured and the tubes at the base of the style and in the ovary were counted.

The mean fruit set percentages obtained revealed two clear groups. The cultivars in the first group-'Velázquez Fino', 'Gitano', 'Pepito de1 Cura', and 'Velázquez Tardío'seemed to be self-incompatible, since there was $0 \%$ fruit set (Table 1). The cultivars in the second group- 'Carrascal', 'Candelo', and 'Pepito de1 Rubio'- had a sufficiently high fruit set that confirmed their self-compatibility. 'Moniqui Fino' had a fruit set of $0.7 \%$, or one fruit from 153 pollinated flowers; this percentage was much too low to consider it selfcompatible.

Pollinating eight cultivars in the field with their own pollen and with pollen from other

Table 1. Fruit set percentage of apricot cultivars following self-pollination.

\begin{tabular}{lc}
\hline \hline Cultivar & Fruit set $(\%)^{2}$ \\
\hline Velázquez Fino & 0 \\
Gitano & 0 \\
Pepito del Rubio & 7.6 \\
Pepito del Cura & 0 \\
Velázquez Tardío & 0 \\
Moniquí Fino & 0.7 \\
Carrascal & 12.3 \\
Candelo & 9.4 \\
\hline
\end{tabular}

${ }^{2}$ Minimum of 150 flowers bagged per cultivar.

Table 2. Fruit set from controlled self- and crosspollinations of apricot cultivars.

\begin{tabular}{llc}
\hline $\begin{array}{l}\text { Female } \\
\text { cultivar }\end{array}$ & \multicolumn{1}{c}{$\begin{array}{c}\text { Pollen } \\
\text { cultivar }\end{array}$} & $\begin{array}{c}\text { Fruit set } \\
(\%)^{2}\end{array}$ \\
\hline Velázquez Fino & Velázquez Fino & 1.1 \\
& Gitano & 40.8 \\
Gitano & Candelo & 36.4 \\
& Gitano & 2.0 \\
& Velázquez Fino & 38.7 \\
Pepito del Rubio & Candelo & 50.8 \\
& Pepito del Rubio & 41.1 \\
& Pepito del Cura & 48.0 \\
Pepito del Cura & Carrascal & 45.0 \\
& Pepito del Cura & 0 \\
Velázquez Tardío & Pepito del Rubio & 16.2 \\
& Carrascal & 39 \\
& Velázquez Tardío & 2.3 \\
Moniquí Fino & Velázquez Fino & 46.8 \\
& Candelo & 30.2 \\
& Moniquí Fino & 0.8 \\
Carrascal & Pepito del Rubio & 54.1 \\
& Carrascal & 53.7 \\
& Carrascal & 34.0 \\
Candelo & Pepito del Rubio & 38.9 \\
& Candelo & 49.5 \\
& Candelo & 53.1 \\
& Pepito del Rubio & 43.1 \\
& Carrascal & 27.4 \\
\hline
\end{tabular}

${ }^{\mathrm{z}}$ Minimum of 150 flowers emasculated and pollinated per combination. 
Table 3. Germination and pollen tube growth of apricot cultivars in the laboratory, after 12 and $48 \mathrm{~h}$ at $20 \mathrm{C}$.

\begin{tabular}{|c|c|c|c|c|c|}
\hline \multicolumn{2}{|c|}{ Cultivar parent } & \multicolumn{2}{|c|}{$\begin{array}{l}\text { Germination, longest pollen } \\
\text { tube mean length (mm) }\end{array}$} & \multicolumn{2}{|c|}{$\begin{array}{l}\text { Pollen tube no. } \\
\text { after } 48 \mathrm{~h}\end{array}$} \\
\hline Female & Pollen & After $12 \mathrm{~h}$ & After $48 \mathrm{~h}$ & Style & Ovary \\
\hline \multirow[t]{3}{*}{ Velázquez Fino } & Velázquez Fino & $\mathrm{L}^{z}, 3.2$ & $\mathrm{M}, 8.7$ & 0 & 0 \\
\hline & Gitano & $\mathrm{M}^{\mathrm{y}}, 4.9$ & M, 14.8 & 0.9 & 0.3 \\
\hline & Candelo & $\mathrm{H}^{\mathrm{x}}, 5.0$ & $\mathrm{H}, 15.1$ & 3 & 1.6 \\
\hline \multirow[t]{3}{*}{ Gitano } & Gitano & $\mathrm{H}, \mathbf{8 . 0}$ & $\mathrm{H}, 12.3$ & 0 & 0 \\
\hline & Velázquez Fino & M, 2.2 & M, 15.9 & 0.3 & 0.2 \\
\hline & Candelo & $\mathrm{H}, 4.8$ & H, 18.8 & 0.1 & 0.1 \\
\hline \multirow[t]{3}{*}{ Pepito del Rubio } & Pepito del Rubio & $\mathrm{H}, 8.8$ & $\mathrm{H}, 17.3$ & 1 & 0.6 \\
\hline & Pepito del Cura & L-M, 7.1 & M, 18.7 & 1.2 & 1 \\
\hline & Carrascal & $\mathrm{H}, 6.7$ & $\mathrm{H}, 18.4$ & 0.7 & 0.4 \\
\hline \multirow{3}{*}{ Pepito del Cura } & Pepito del Cura & $\mathrm{L}-\mathrm{M}, 4.0$ & $\mathrm{~L}-\mathrm{M}, 6.4$ & 0 & 0 \\
\hline & Pepito del Rubio & $\mathbf{M}-\mathbf{H}, 3.8$ & $\mathrm{H}, 17.5$ & 0.1 & 0 \\
\hline & Carrascal & M-H, 3.7 & $\mathrm{H}, 16.8$ & 2.1 & 0.8 \\
\hline \multirow[t]{3}{*}{ Velázquez Tardío } & Velázquez Tardío & H, 7.1 & $\mathrm{H}, 12.2$ & 0 & 0 \\
\hline & Velázquez Fino & M, 5.4 & M, 12.8 & 0 & 0 \\
\hline & Moniquí Fino & $\mathrm{H}, 7.2$ & $\mathrm{H}, 15.1$ & 1 & 0.2 \\
\hline \multirow[t]{3}{*}{ Moniquí Fino } & Moniquí Fino & $\mathrm{H}, 5.0$ & $\mathrm{H}, 12.8$ & 0 & 0 \\
\hline & Pepito del Rubio & $\mathrm{H}, 8.9$ & $\mathrm{H}, 18.1$ & 0.1 & 0 \\
\hline & Carrascal & $\mathrm{H}, 7.8$ & $\mathrm{H}, 17.8$ & 0.1 & 0.1 \\
\hline
\end{tabular}

${ }^{2} \mathbf{L}=$ low, $<15$ pollen grains germinated.

${ }^{9} \mathbf{M}=$ medium, $15-40$ pollen grains germinated.

${ }^{\mathrm{x}} \mathrm{H}=$ high, $>40$ pollen grains germinated.

cultivars resulted in mean fruit set percentages of $16 \%$ to $54 \%$ in compatible crosses (Table 2). These results confirmed the grouping determined by natural self-pollination (Table 1).

Self-pollination produced some fruit in all self-incompatible cultivars except for 'Pepito de1 Cura', although fruit set was low. No cross-incompatibilities were found. Fruit set for self-pollinated, self-compatible cultivars was equal to that from cross-pollinations.

In 33 laboratory pollinations among the eight cultivars studied, pollen germination generally was good, and there was no relationship between the degree of germination and cross-compatibility (Tables 3 and 4). The average length of the longest pollen tubes was 2.2 to $8.9 \mathrm{~mm}$ after $12 \mathrm{~h}$ (Table 3); however, there did not seem to be a relationship between these values and cross-incompatibility. After $48 \mathrm{~h}$, pollen tube length was more uniform (Tables 3 and 4). The incompatible combinations had less pollen tube growth. In general, pollen tube growth rate decreased in selfincompatible combinations.

After $72 \mathrm{~h}$ (Table 4), many of the tubes had penetrated the ovary, and it was not possible to measure the longest pollen tube. The number of tubes reaching the base of the style and the ovary confirmed the field fruit set results (Tables 3 and 4). No pollen tubes were found in any of the self-incompatible cultivars.

In the cross 'Pepito de1 Cura' $\times$ 'Pepito de 1 Rubio', pollen tubes were found at the base of the style after $48 \mathrm{~h}$, but not in the ovary. In the cross 'Velázquez Tardío' × 'Velázquez Fino', no tubes were found in the base of the style or in the ovary after $48 \mathrm{~h}$, although some were found after $72 \mathrm{~h}$.

The fact that five out of the eight cultivars tested were self-incompatible is surprising, because it is generally accepted that most apricots are self-compatible (Cappellini and Limongelli, 1981; Limongelli and Cappellini, 1978; Schultz, 1948; Suranyi, 1976), although self-incompatible cultivars have been reported (Egea et al., 1989; Lamb and Stiles, 1983; Nyútjó et al., 1985; Schultz, 1948).

The self-incompatibility of these Spanish cultivars might be the result of crossing two apricot groups from Europe and North Africa, as suggested by Crossa-Raynaud (1961). This crossing might also explain the genetic variability observed among local apricots in the Murcia region. This theory seems to be supported by the review of local cultivars carried out by Egea et al. (1988).

The examples of self-incompatibility are clear in the case of bagged branches and in the case of hand pollination with the flower's own pollen. However, someresults, especially from hand pollination, suggest a small degree of compatibility, since low fruit set occurred. With regard to hand pollination, there may have been an error, or a flower, despite its being emasculated, may have been visited by bees. This result is more difficult to explain in bagged flowers, however, although it only occurred in 'Moniquí Fino' and at a low percentage. This case may be an example of pseudocompatibility, which has been reported as a nongenetic condition that is environmentally influenced by external (temperature) or internal (flower age) conditions (Van Gastel, 1976).

Physiological factors can also influence fruit set such as flower age. Young flower buds do not yet have biochemical barriers, which are no longer effective in old flowers (VanGastel, 1976; Williams and Maier, 1977). Similar results can also be obtained artificially by keeping the flowers at specific temperatures during pollen tube growth (Williams and Maier, 1977) or by heating the pistil at specific periods (Hiratsuka et al., 1989).

In incompatible combinations, microscopic examinations confirmed that there were no pollen tubes reaching the ovary. Although one case of cross-incompatibility has been described in local apricot cultivars (Egea et al., 1989), no cases appeared in the 25 different combinations of cultivars in our study.

Table 4. Germination and pollen tube growth of apricot cultivars in the laboratory after 48 and $72 \mathrm{~h}$ at $20 \mathrm{C}$.

\begin{tabular}{|c|c|c|c|c|c|c|c|}
\hline \multirow{2}{*}{\multicolumn{2}{|c|}{ Cultivar parent }} & \multirow{2}{*}{\multicolumn{2}{|c|}{$\begin{array}{c}\text { Germination, longest pollen } \\
\text { tube mean length }(\mathrm{mm})\end{array}$}} & \multicolumn{4}{|c|}{ Pollen tube no. } \\
\hline & & & & \multicolumn{2}{|c|}{ After $48 \mathrm{~h}$} & \multicolumn{2}{|c|}{ After $72 \mathrm{~h}$} \\
\hline Female & Pollen & After $48 \mathrm{~h}$ & After $72 \mathrm{~h}$ & Style & $\overline{\text { Ovary }}$ & Style & Ovary \\
\hline \multirow[t]{2}{*}{ Velázquez Fino } & Pepito del Rubio & $\mathbf{H}^{x}, 14.4$ & $\mathrm{H}, \mathrm{NPT}^{y}$ & 2.2 & 1.3 & 10.7 & 7.2 \\
\hline & Carrascal & $\mathbf{M}^{\mathrm{x}}, 14.8$ & H, NPT & 3.4 & 1.7 & 7.9 & 5.5 \\
\hline \multirow[t]{2}{*}{ Gitano } & Pepito del Rubio & $\mathrm{H}, 17.8$ & $\mathrm{H}, \mathrm{NPT}$ & 0.9 & 0.4 & 6.2 & 3.8 \\
\hline & Carrascal & $H, 17.3$ & H, NPT & 0.3 & 0 & 4.3 & 2.9 \\
\hline \multirow[t]{2}{*}{ Pepito del Rubio } & Velázquez Fino & H, 16.9 & H, NPT & 1.1 & 0.6 & 5.8 & 4.2 \\
\hline & Gitano & $\mathrm{H}, 16.4$ & $\mathrm{H}, \mathrm{NPT}$ & 1.7 & 0.8 & 10.7 & 6.9 \\
\hline \multirow[t]{3}{*}{ Velázquez Tardío } & Velázquez Tardío & H, 12.7 & M, 13.6 & 0 & 0 & 0 & 0 \\
\hline & Velázquez Fino & H, 17.4 & $\mathrm{H}, \mathrm{NPT}$ & 0.4 & 0 & 9.8 & 2.7 \\
\hline & Candelo & $\mathrm{H}, \mathrm{NPT}$ & $\mathrm{H}, \mathrm{NPT}$ & 1.7 & 1.3 & 7.7 & 3.8 \\
\hline \multirow[t]{2}{*}{ Moniquí Fino } & Velázquez Fino & H, 17.2 & H, NPT & 0 & 0 & 2 & 1.2 \\
\hline & Gitano & $\mathrm{H}, 18$ & H, NPT & 0.1 & 0 & 4.8 & 2.9 \\
\hline \multirow[t]{3}{*}{ Candelo } & Candelo & $\mathrm{H}, 15.5$ & $\mathrm{H}, 15.1$ & 3.5 & 1.9 & 5.5 & 4.2 \\
\hline & Carrascal & $\mathrm{H}, 15.7$ & H, NPT & 2.6 & 1 & 7.6 & 6.5 \\
\hline & Pepito del Rubio & $\mathrm{H}, 16$ & H, NPT & 1.6 & 0.7 & 7.3 & 6 \\
\hline \multirow[t]{3}{*}{ Carrascal } & Carrascal & $\mathrm{H}, 18.4$ & $\mathrm{H}, 18.6$ & 1.6 & 1 & 3.1 & 2.1 \\
\hline & Pepito del Rubio & $H, 18.6$ & H, 17.8 & 1.1 & 0.7 & 3.8 & 2.6 \\
\hline & Candelo & $\mathrm{H}, 18.5$ & H, 19.1 & 1 & 0.7 & 2.5 & 1.9 \\
\hline
\end{tabular}

${ }^{{ }^{2} \mathrm{H}}=$ high; $>40$ pollen grains germinated.

${ }^{\mathrm{y}} \mathrm{NPT}=$ no pollen tube.

${ }^{\times} \mathrm{M}=$ medium; $15-40$ pollen grains germinated. 
Controlled cross-pollination gave fruit sets that, although varied from one combination to another, were in all cases sufficient to provide a good harvest. There was no difference in fruit set percentages obtained in self-compatible cultivars, whether self-pollinated or inter-pollinated. This result contrasts with the results in almond studies (Godini, 1981; Socias i Company and Felipe, 1987; Socias i Company et al., 1976).

Our research confirmed the self-incompatibility of 'Moniqui Fino' and 'Velázquez Tardío' previously reported by Egea et al. (1989) and led to the discovery of self-incompatibility of 'Gitano', 'Velázquez Fino', and 'Pepito del Cura'.

In Murcia, the many self-incompatible cultivars make cross-pollination necessary for commercial apricot production. Low production in some cases cannot be explained solely by self-incompatibility. Other factors,probably related to flower biology, may also play an important part.

Our results indicate that single-cultivar apricot orchards should be avoided. In addition, self-incompatible cultivars should not be used in future breeding programs. Self-compatible cultivars must be selected for breeding programs to increase apricot production and to eliminate the need for planting additional cultivars as pollinizers.

\section{Literature Cited}

Bailey, C.H. and L.F. Hough. 1975. Apricots, p. 367-383. In: J. Janick and J.N. Moore (eds.).
Advances in fruit breeding. Purdue Univ. Press, West Lafayette, Ind.

Cappellini, P. and F. Limongelli. 1981. Indagine sull'autofertilitá delle piu importanti cultivar di albicocco vesuviane. Ann. Ist. Sper. Fruttic. XII:47-55.

Crossa-Raynaud, P. 1961. L'abricot et le climat. Journees Nationales de l'abricotier. Perpignan, Menard, Toulouse. p. 55-57.

Egea, J., J.E. Garcia, L. Egea, and T. Berenguer. 1991. Self-incompatibility in apricot cultivars. Acta Hort. 293:285-293.

Egea, L., T. Berenguer, J. Egea, and J.E. Garcia. 1988. Origen, situación y caracteristicas de las variedades de albaricoquero de Murcia. Anales de Edafologia y Agrobiologia. XLVII(5-6):9991011.

Free, J.B. and Y. Spencer-Booth. 1964, The effect of distance from pollinizer varieties on the fruit set of apple, pear and sweet-cherry trees. J: Hort. Sci. 39:54-60.

Garcia, J.E., J. Egea, L. Egea, and T. Berenguer. 1988. The floral biology of certain apricot cultivars in Murcia. Adv. Hort. Sci. 2:84-87.

Godini, A. 1981. Observing pollen tube growth into selfed and crossed styles of two self-compatible almond cultivars by means of fluorescence. Riv. Ortoflorofrutt. Italiana 65:135-142.

Godini, A., E. Ferrara, A. Reina, V. Giorgio, and F. Guida. 1979. Contributo alla conoscenza delle cultivar di mandorlo (Prunus amygdalus, Batsch) della puglia: 3/ Un trienio di prove d'impollinazione incrociata. Atti 3a Riunione GREMPA, Bari p. $237-251$

Hiratsuka, S., T. Tezuka, and Y. Yamamoto. 1989. Analysis of self-incompatibility reaction in Easter lily by using heat treatments. J. Amer. Soc. Hort. Sci. 114:505-508.

Lamb, R.C. and W.C. Stiles. 1983. Apricots for
New York state. New York Food \& Life Sci. Bul. (100:):1-4

Limongelli, F. and P. Cappellini. 1978. Indagini preliminare sull' autofertilitá delle piu importanti cultivar di albicocco "vesuviane." Riv. Ortoflorofrutt. Italiana 62:623-631.

Linskens, H.F. and K. Esser. 1957. Über eine spezifische Anfärbung der Pollenschläuche im Griffel und die Zahl der Kallosepfropfen nach Selbstung und Fremdung. Naturwissenschaften 44:16.

Nyútjó, F., S. Jr. Brózik, S. Brózik, and J. Nyéki. 1985. Fruit set in apricot varieties. Acta Agronomica Academiae Scientiarum Hungaricae 34(1-2):65-72.

Schultz, J.H. 1948. Self-incompatibility in apricots. Proc. Amer. Soc. Hort. Sci. 51:171-174.

Socias i Company, R. and A.J. Felipe. 1987. Pollen tube growth and fruit set in a self-compatible almond selection. HortScience 22:113-116.

Socias i Company, R., D.E. Kester, and M.V. Bradley. 1976. Effects of temperature and genotype on pollen tube growth in some self-incompatible and self-compatible almond cultivars. J. Amer. Soc. Hort. Sci. 101:490-493.

Suranyi, D. 1976. Differentiation of self-fertility and self-sterility in Prunus by stamen number/ pistil length ratio. HortScience 11:406-407.

Van Gastel, A.J.G. 1976. Mutability of the selfincompatibility locus and identification of the Sbearing chromosome in Nicotiana alata. $\mathrm{PhD}$ Diss., Centre for Agr. Publishing and Documentation, Wageningen, The Netherlands.

Williams, R.R. and M. Maier. 1977. Pseudocompatibility after self pollination of the apple Cox's Orange Pippin. J. Hon. Sci. 52:475483. 